\title{
UPAYA MENINGKATKAN HASIL BELAJAR MATEMATIKA SISWA KELAS VIII-F SMP NEGERI 22 SURABAYA MELALUI PENERAPAN MODEL PEMBELAJARAN PROBLEM BASED LEARNING TAHUN PELAJARAN 2018-2019
}

\author{
Sunyoto Hadi Prayitno \\ Pendadidikan Matematika Universitas PGRI Adi Buana Surabaya \\ nyoto_hp@unipasby.ac.id \\ Sjaiful Muttaqien \\ Guru Matematika SMP Negeri 22 Surabaya \\ sjaiful muttaqien@gmail.com
}

\begin{abstract}
Abstrak
Pengalaman siswa dalam menyelesaikan masalah melalui penemuan, merupakan prasyarat untuk berpikir kritis dan analitis siswa dalam mengkonstruk hasil belajarnya, sehingga akan terbentuk proses skemata pengetahuan dalam memorinya siswa yang siap digunakan kembali saat pengetahuan tersebut dibutuhkan. Kurang optimalnya hasil belajar siswa disebabkan oleh beberapa faktor, salah satu di antaranya adalah rendahnya perhatian dan kurangnya konsentrasi siswa dalam mengikuti pembelajaran matematika. Guru sering memberikan pelajaran dalam bentuk ceramah dan tanya-jawab, sehingga siswa kurang termotivasi untuk mengembangkan kemampuan berfikir kreatif dalam penyelesaikan masalah. Tujuan dari penelitian ini adalah untuk mengetahui ada tidaknya peneningkatan hasil belajar matematika siswa setelah diterapkannya model pembelajaran problem based learning. Jenis penelitian ini adalah penelitian tindakan kelas dengan dua siklus, dimana setiap siklus terdiri dari kegiatan perencanaan, pelaksanaan, observasi, dan refleksi. Pengambilan data dilaksanakan dengan tes tulis pada materi persamaan linier dua variabel. Penelitian ini dilaksanakan di kelas VIIIF SMP Negeri 22 Surabaya dengan jumlah siswa 32 siswa. Hasil dalam penelitian ini didapatkan ketuntasan klasikal siswa pada pra siklus sebesar $78,13 \%$, siklus I $84,38 \%$ dan Siklus II 90,63\%. Dengan demikian dapat dikatakan bahwa Penerapan model pembelajaran problem based learning dapat meningkatkan hasil belajar matematika siswa.
\end{abstract}

Kata Kunci: hasil belajar matematika, problem based learning

\begin{abstract}
Students' experience in solving problems through discovery is a prerequisite for students' critical and analytical thinking in constructing their learning outcomes, so that a knowledge system process will be formed in their students' memories that is ready to be reused when such knowledge is needed. Less optimal student learning outcomes are caused by several factors, one of which
\end{abstract}


is the low attention and lack of concentration of students in following mathematics learning. Teachers often provide lessons in the form of lectures and questions and answers, so students are less motivated to develop creative thinking skills in solving problems. The purpose of this study is to determine whether there is an increase in student mathematics learning outcomes after the implementation of problem based learning learning models. This type of research is classroom action research with two cycles, where each cycle consists of activities of planning, implementation, observation, and reflection. Data retrieval is carried out by a written test on two linear variables. This research was conducted in class VIII-F of SMP Negeri 22 Surabaya with 32 students. The results in this study showed that students' classical completeness in the pre-cycle was $78.13 \%$, the first cycle was $84.38 \%$ and the second cycle was $90.63 \%$.Thus it can be said that the application of problem based learning learning models can improve students' mathematics learning outcomes.

Keywords: mathematics learning outcomes, problem based learning

\section{PENDAHULUAN}

Pendidikan memegang peranan penting dalam kehidupan manusia, karena dengan pendidikan manusia akan memiliki ilmu pengetahuan yang lebih baik dan menjadi sumber daya manusia yang berkualitas. Untuk mendapatkan pendidikan yang baik dan berkembang, maka diperlukan suatu perancangan pembelajaran sesuai dengan tujuan nasional pendidikan. UU No. 20 tahun 2003 dalam mewujudkan potensi diri, harus menempuh pendidikan yang diimplementasikan dalam proses pembelajaran.

Pentingnya matematika dari fakta/teori bahwa kemampuan pemecahan masalah siswa rendah. Oleh karena itu, tugas guru bukan sekedar mengajarkan ilmu semata kepada siswa, melainkan membantu siswa belajar. Salah satunya yaitu dengan tekanan pembelajaran harus pada aktivitas pembelajaran siswa untuk belajar, baik secara aktif, mental maupun fisik. Tugas guru adalah memfasilitasi siswa dalam belajar. Dalam pembelajaran yang bermakna perlu dua aktivitas, yakni aktif dalam berfikir dan aktif dalam berbuat (Suparno, dkk (2002). Pada pembelajaran ini melibatkan siswa pada perbuatan nyata dengan hasil keterlibatan berpikir siswa terhadap obyek belajar dan pengalaman hasil perbuatan siswa itu sendiri, sehingga dapat diperoleh kerangka berpikir dan pengetahuan yang dimiliki siswa. Untuk mencapai tujuan pembelajaran, salah satu kemampuan yang harus dikuasai siswa adalah kemampuan pemecahan masalah masalah matematika. Menurut 
Suryadi,dkk (Suherman, dkk UPI 2003: 83), pemecahan masalah matematika merupakan salah salah satu kegiatan matematika yang dianggap penting, baik oleh guru maupun siswa di semua tingkatan mulai dari SD sampai SMU.

Kemampuan pemecahan masalah matematika siswa dapat dilihat dari proses hasil belajar siswa. Sehingga proses belajar yang akan dihasilkan siswa dinamakan hasil belajar. Hasil belajar merupakan ukuran atau tingkat keberhasilan yang dapat dicapai oleh seorang siswa berdasarkan pengalaman yang diperoleh setelah dilakukan evaluasi berupa tes dan biasanya di wujudkan dengan nilai atau angka-angka tertentu (Nana Sudjana 2010: 22). Banyak faktor yang menyebabkan rendahnya kemampuan pemecahan masalah matematika, diantaranya siswa kurang memahami apa yang dimaksud oleh soal, siswa kurang berlatih terkait dengan pemecahan masalah, dan siswa kurang konsentrasi saat pembelajaran berlangsung.

Siswa kurang konsentrasi, umumnya mereka kurang tertarik terhadap cara mengajar dan belajar matematika yang menggunakan cara konvensional. Ketidaksenangan siswa terhadap pelajaran matematika disebabkan guru kurang mampu mengajarkan materi matematika secara profesional. Dengan kata lain, guru kurang bisa menggunakan cara mengajar matematika yang bisa menumbuhkembangkan minat atau motivasi siswa untuk berbuat dan belajar, sehingga menyebabkan hasil belajarnyapun kurang optimal.

Salah satu cara untuk meningkatkan hasil belajar siswa dalam proses pembelajaran adalah dengan mengganti model pembelajaran yang selama ini kurang diminati lagi oleh siswa, seperti pembelajaran yang dilakukan dengan ceramah dan tanya-jawab, model pembelajaran ini membuat siswa jenuh dan tidak kreatif. Suasana belajar mengajar yang diharapkan adalah menjadikan siswa sebagai subjek yang berupaya menggali sendiri, memecahkan sendiri masalah-masalah dari suatu konsep yang dipelajari, sedangkan guru lebih banyak bertindak sebagai motivator dan fasilitator. Situasi belajar yang diharapkan di sini adalah siswa yang lebih banyak berperan aktif.

Model pembelajaran dalam matematika yang dapat membangun minat, motivasi dan tingkat pemahaman siswa merupakan model-model pembelajaran telah 
dikembangkan dan bersifat inovatif. kembali saat pengetahuan tersebut Misalnya melalui cooperative learning dibutuhkan.

serta pembelajaran yang berbasis Dengan terbentuknya proses skemata Contextual Teaching and Learning dalam diri siswa saat mengkonstruk hasil $(C T L)$. Salah satu model pembelajaran belajarnya, akan memudahkan siswa kontekstual adalah "problem based dalam menyelesaikan masalah-masalah learning" yakni pembelajaran yang matematika lain yang serupa, sehingga menekankan siswa mengawali dengan pengajuan masalah, kemudian menganalisa masalah yang ada dan berusaha untuk menemukan penyelesaiannya. Kegiatan ini akan membuat siswa secara aktif mengonstruksi hasil belajar.

Menurut Ward (Ngalimun 2012: 89), Problem Based Learning (PBL) adalah suatu model pembelajaran yang melibatkan siswa untuk memecahkan suatu masalah dan sekaligus memiliki ketrampilan dalam memecahan masalah tersebut. Sehingga siswa siap untuk berfikir kritis dan analisis yang gunanya untuk mencari dan menggunakan sumber pembelajaran yang sesuai.

Pengalaman siswa dalam menyelesaikan masalah melalui penemuan, merupakan prasyarat untuk berpikir kritis dan analitis siswa dalam mengkonstruk hasil belajarnya, sehingga akan terbentuk proses skemata pengetahuan dalam memorinya siswa yang siap digunakan akan terjadi peningkatan hasil belajar siswa.

Berdasarkan pengamatan atau observasi pendahuluan yang peneliti lakukan, ditemukan bahwa siswa SMP Negeri 22 Surabaya dalam melaksanakan diskusi kelas masih kurang berani dalam mengemukakan pendapat, kurang berani mengajukan pertanyaan, dan kurang percaya diri dalam melakukan presentasi. Kondisi seperti ini yang menyebabkan hasil belajar yang diperoleh juga belum optimal. Hal ini dapat kita lihat dari nilai rata-rata hasil ulangan harian yang hanya mencapai 78,75 dengan standart ketuntasan minimal 80.

Kurang optimalnya hasil belajar siswa disebabkan oleh beberapa faktor, salah satu di antaranya adalah rendahnya perhatian dan kurangnya konsentrasi siswa dalam mengikuti pembelajaran matematika. Guru sering memberikan pelajaran dalam bentuk ceramah dan tanya-jawab, sehingga siswa kurang 
termotivasi untuk mengembangkan kemampuan berfikir kreatif dalam penyelesaikan masalah.

Sesuai pengalaman yang peneliti hadapi dalam proses pembelajaran matematika selama melakukan Pemagangan Dosen di Sekolah (PDS), siswa yang kurang konsentrasi dalam pembelajaran maka peneliti berusaha mencarikan model pembelajaran lain, sehingga pembelajaran lebih bermakna dan lebih berkualitas.

Berdasarkan latar belakang yang telah peneliti uraikan, maka dalam penelitian ini peneliti mengambil sebuah judul yaitu: "Upaya Meningkatkan Hasil Belajar Matematika Siswa Kelas VIII-F SMP Negeri 22 Surabaya Melalui Penerapan Model Pembelajaran Problem Based Learning Tahun Pelajaran 2018-2019”.

Penelitian ini bertujuan untuk mendeskripsikan ada tidaknya peningkatan hasil belajar matematika siswa kelas VIII-F SMP Negeri 22 Surabaya melalui penerapan model pembelajaran problem based learning.

Dari judul penelitian yang peneliti tulis, agar tidak menimbulkan salah pengertian maka perlu peneliti definisikan secara operasional terkait dengan hasil belajar dan model pembelajaran problem based learning.
Hasil belajar matematika siswa adalah hasil tes matematika siswa setelah diberikan pembelajaran materi sistem persamaan linier dua variabel dengan menerapkan model pembelajaran problem based learning.

Problem based learning merupakan model pembelajaran yang diterapkan dalam penelitian dengan menggunakan langkah-langkah sebagai berikut; (1) orientasi siswa pada masalah, (2) mengorganisasi siswa untuk belajar, (3) membimbing penyelidikan individu maupun kelompok, (4) mengembangkan dan menyajikan hasil karya, (5) menganalisis dan mengevaluasi proses pemecahan masalah.

Untuk memudahkan peneliti dalam melaksanakan penelitian, disajikan beberapa teori sebagai berikut:

\section{Model Pembelajaran Problem}

\section{Based Learning}

Model pembelajaran Problem Based Learning (PBL) merupakan suatu pembelajaran yang dimulai dengan menghadapkan siswa, kepada suatu permasalahan yang terdapat dalam dunia nyata dan menuntunnya untuk dapat menyelesaikan atau memecahkan masalah tersebut melalui kegiatan atau pengalaman belajar yang dilakukan 
selama proses pembelajaran, (Isro'atun dan Amelia Rosmala, 2018: 44).

Disisi lain menurut Barrow (Huda, 2013: 271) pembelajaran berbasis masalah PBL (Problem Based Learning) didefinisikan sebagai pembelajaran yang diperoleh melalui proses menuju pemahaman akan resolusi suatu masalah.

Sedangkan menurut Herman (Isro'atun, 2018: 44), Model Problem Based Learning dapat diartikan sebagai suatu pembelajaran yang mengacu kepada keempat pilar pendidikan universal, yaitu belajar memahami, belajar melaksanakan atau melakukan, belajar menjadi diri sendiri, belajar bekerja sama atau hidup dalam kebersamaan.

Pembelajaran berbasis masalah memiliki beberapa sintak yang dimulai dari permasalahan dan berakhir pada solusi dari permasalahan tersebut. Adapun tahapan pembelajaran berbasis masalah (PBM) menurut Trianto (Ngalimun, 2012: 96) yaitu sebagai berikut:

a. Orientasi siswa pada masalah. Tahap orientasi adalah tahap pengenalan, pada langkah yang pertama guru melakukan pengenalan kepada siswa mengenai masalah apa yang akan dipecahkan oleh siswa pada kegiatan pembelajaran, dan guru juga memberika motivasi kepada siswa untuk mengungkapkan dan memahami masalah tersebut.

Model pembelajaran problem based learning diawali dengan yang namanya tahap orientasi atau pengenalan, yang didalamnya mencakup:

1) Pencapaian akan tujuan yang hendak guru capai

2) Penjelasan akan logistik yang diperlukan

3) Pemberian suatu masalah kepada siswa

4) Pemberian motivasi agar siswa terlibat langsung dan berperan aktif.

b. Mengorganisasi siswa untuk belajar Pada langkah kedua, guru mengorganisasi siswa dalam tugas belajar dengan masalah yang akan dipecahkan oleh siswa. Kemudian siswa dikelompokkan dan diberi tugas beljar untuk menyelesaikan permasalahan bersama.

c. Membimbing penyelidikan individual maupun kelompok

Guru membimbing ketika siswa melakukan penyelidikan terkait dengan masalah yang sedang dipecahkan, baik secara individu maupun kelompok.

d. Mengembangkan dan menyajikan hasil karya 
Hasil karya ini merupakan hasil pemikiran siswa, mengenai permecahan masalah yang baru saja dilakukan oleh siswa. Penyajian dapat berupa laporan tertulis, laporan lisan, maupun model.

$$
\begin{aligned}
& \text { e. Menganalisis dan mengevaluasi } \\
& \text { proses pemecahan masalah }
\end{aligned}
$$

Pada langkah ini guru memiliki peranan penting. Guru bertugas untuk menganalisis dan mengevaluasi apakah pemecahan masalah yang dilakukan oleh siswa sudah benar atau belum. Guru juga melakukan klarifikasi jika terdapat kesalahan-kesalahan yang dilakukan oleh siswa.

Dari beberapa definisi di atas, maka dapat disimpulkan bahwa model pembelajaraan Problem Based Learning merupakan sebuah pendekatan pembelajaran yang berusaha menerapkan masalah yang terjadi dalam dunia nyata sebagai sebuah konteks bagi para siswa dalam berlatih bagaimana cara berfikir kritis dan mendapatkan ketrampilan dalam pemecahan masalah, serta tak terlupakan untuk mendapatkan pengetahuan sekaligus konsep yang penting dari materi ajar yang dibicarakan

Menurut Barraw dan Min Liu (Isrok'atun, 2018: 45) Problem Based Learning memiliki ciri-ciri yakni sebagai berikut: a. Learning is Student-Centered. Proses pembelajaran yang lebih memfokuskan kepada aktivitas siswa, sehingga pembelajaran berpusat kepada siswa. Oleh karena itu, proses pembelajarannya di dasarkan pada konsep konstruktivisme.

b. Authentic Problems From the Organizing focus for Learning

c. New Informationis Acquired Through Self-Directed Learning

d. Learning Occurs in Small Groups

e. Teachers Act as Facilitators

\section{Hasil Belajar Matematika Siswa}

Dimyati (2010:24) menyatakan bahwa hasil belajar merupakan tingkat perkembangan mental yang lebih baik dibandingkan pada saat sebelum belajar.

Susanto (2016:5) menyatakan bahwa hasil belajar yaitu perubahan-perubahan yang terjadi pada diri siswa, baik yang menyangkut aspek kognitif, afektif, dan psikomotor sebagai hasil belajar.

Dari kedua pendapat diatas dapat disimpulkan bahwa hasil belajar merupakan hasil yang menunjukkan kemampuan seseorang siswa dalam menguasai bahan pelajarannya. Dengan demikian dapat dikatakan bahwa hasil belajar matematika merupakan 
kemampuan seseorang dalam menguasai pelajaran matematika sebagai hasil interaksi edukatif yang ditunjukkan dengan nilai hasil tes. Dalam hal ini hasil tes matematika materi sistem persamaan linier dua variabel.

\section{Materi Sistem Persamaan Linier}

\section{Dua Variabel (SPLDV)}

Sistem persamaan linier dua variabel adalah persamaan linier yang mempunyai dua variabel dan masing-masing variabel tersebut berpangkat satu. Dua atau lebih persamaan variabel dikatakan sebagai suatu SPLDV apabila variabel kedua persamaan sama.

Bentuk umum : $\left\{\begin{array}{l}a_{1} x+b_{1} y=c_{1} \\ a_{2} x+b_{2} y=c_{2} \text {, dengan }\end{array}\right.$ a, b, c anggota $\mathrm{R}$

Terdapat tiga cara untuk menyelesaikan sistem persamaaan linier dua variabel, yaitu dengan substitusi, eliminasi dan gabungan elminasi dan substitusi.

Selesaikan sistem persamaan berikut

$\mathrm{x}+\mathrm{y}=8, \quad \mathrm{x}-2 \mathrm{y}=2$

Jawab :

\section{Dengan metode substitusi}

$\mathrm{x}+\mathrm{y}=8 \rightarrow \mathrm{x}=8-\mathrm{y}$ disubstitusikan pada $\mathrm{x}-2 \mathrm{y}=2$, menjadi

$$
\begin{aligned}
(8-y)-2 y & =2 \\
8-3 y & =2 \\
3 y & =6 \rightarrow y=2
\end{aligned}
$$

$\mathrm{x}+\mathrm{y}=8 \quad \mathrm{y}=8-\mathrm{x}$ disubstitusi-

kan pada $\mathrm{x}-2 \mathrm{y}=2$, menjadi

$\mathrm{x}-2(8-\mathrm{x})=2$

$3 \mathrm{x}-16=2$

$3 \mathrm{x}=18 \rightarrow \mathrm{x}=6$

Jadi penyelesaian sistem persamaan tersebut adalah $\mathrm{x}=6$ dan $\mathrm{y}=2$

Dengan metode eliminasi

$$
\begin{aligned}
& \mathrm{x}+\mathrm{y}=8 \rightarrow|\mathrm{x} 1| \mathrm{x}+\mathrm{y}=8 \\
& x-2 y=2 \rightarrow|x 1| x-2 y=\frac{2}{6} \\
& \mathrm{y}=2
\end{aligned}
$$

(mengeliminasi variabel $\mathrm{x}$ )

$$
\begin{aligned}
& \mathrm{x}+\mathrm{y}=8 \longrightarrow \mathrm{x}^{2} 2 \mathrm{x}+2 \mathrm{y}=16 \\
& x-2 y=2 \longrightarrow|x 1| x-2 y=2+ \\
& 3 \mathrm{x}=18 \\
& x=6
\end{aligned}
$$

(mengeliminasi variabel y)

Jadi penyelesaian sistem persamaan tersebut adalah $\mathrm{x}=6$ dan $\mathrm{y}=2$

Dengan metode gabungan eliminasi dan substitusi

$$
\begin{aligned}
& \mathrm{x}+\mathrm{y}=8 \rightarrow|\mathrm{x} 1| \mathrm{x}+\mathrm{y}=8
\end{aligned}
$$

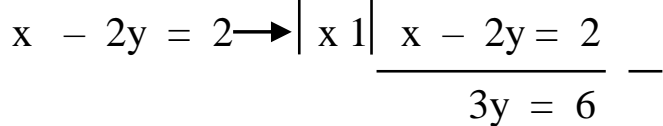

$$
\begin{aligned}
& \mathrm{y}=2
\end{aligned}
$$

(mengeliminasi variabel $\mathrm{x}$ )

$\mathrm{y}=2$ disubstitusikan ke persamaan

$\mathrm{x}+\mathrm{y}=8$ atau $\mathrm{x}-2 \mathrm{y}=2$

Misal $\mathrm{y}=2$ disubstitusikan ke persamaan $\mathrm{x}+\mathrm{y}=8$, maka $\mathrm{x}+2=8$ 


$$
x=6
$$

Jadi penyelesaian sistem persamaan tersebut adalah $\mathrm{x}=6$ dan $\mathrm{y}=2$

Metode penelitian yang digunakan dalam penelitian ini meliputi:

\section{Rancangan Penelitian}

Penelitian ini merupakan penelitian tindakan kelas (PTK) karena penelitian ini dilakukan untuk menyelesaikan masalah pembelajaran di kelas. PTK merupakan suatu penyelidikan atau kajian secara sistematis dan terencana yang dilakukan oleh peneliti atau praktisi (guru) untuk memperbaiki pelajaran dengan mengadakan perbaikan atau perubahan dan mempelajari akibat yang ditimbulkannya.

Penelitian ini menggunakan model Hopkin, yaitu model skema yang menggunakan prosedur kerja yang dipandang sebagai suatu siklus spiral dari perencanaan (planning), tindakan (action), observasi (observation), dan refleksi (reflection).

PTK dalam penelitian ini dilaksanakan selama dua siklus, dimana alur setiap siklus dari tahap-tahap PTK dapat dilihat pada gambar berikut :

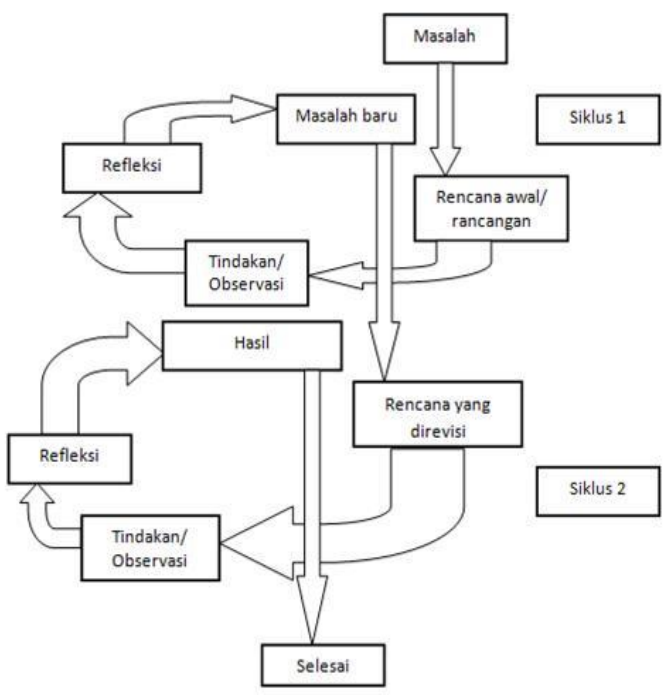

Penjelasan dari alur penelitian tindakan kelas:

a. Pada rancangan/rencana awal, sebelum penelitian peneliti menyusun rumusan masalah, tujuan dan membuat rencana tindakan, termasuk didalamnya ada tahap persiapan yaitu menyiapkan perangkat pembelajaran antara lain menyiapkan rencana pelaksanaan pembelajaran (RPP) atau skenario pembelajaran (SP), menyiapkan Lembar Kerja Siswa (LKS), menyiapkan bukubuku penunjang pembelajaran dan menyusun / menyiapkan soal tes hasil belajar.

b. Tahap Pelaksanaan terdiri dari: kegiatan pendahuluan, kegiatan inti, dan kegiatan penutup yang mengikuti 
langkah-langkah pembelajaran problem based learning

c. c. Tahap refleksi, dilakukan setelah data hasil tes siklus pertama dianalisis.

d. d. Setelah melakukan refleksi jika masalah belum tuntas, pengamat membuat rancangan yang direvisi untuk dijadikan acuan dalam melakukan tindakan pada siklus berikutnya.

Subjek, Waktu, dan Lokasi Penelitian

Subjek pada penelitian ini yaitu siswa kelas VIII-F SMP Negeri 22 Surabaya tahun ajaran 2018-2019 sebanyak 38 siswa, namun yang mengikuti hingga akhir penelitian sebanyak 32 siswa.

Peneltian ini dilaksanakan mulai bulan Agustus hingga Oktober 2018 di SMP Negeri 22 Surabaya.

\section{Instrumen Penelitian}

Instrumen yang digunakan dalam PTK ini terdiri dari:

Rencana Pelaksanaan Pembelajaran(RPP) Buku Siswa

Lembar Kerja Siswa (LKS)

Tes tulis

\section{Teknik Pengumpulan Data}

Teknik pengumpulan data yang peneliti gunakan dalam penelitian ini adalah tes tulis sebanyak 3 soal berbentuk tes subyektif.

\section{Teknik Analisis Data}

Teknik analisis yang digunakan adalah deskriptif kualitatif dengan prosentase dari ketuntasan belajar. Wahyu Widada (2004:13) menyatakan bahwa seorang siswa dinyatakan tuntas belajar apabila memiliki daya serap paling sedikit $65 \%$ atau nilai 65, sedangkan ketuntasan klasikal tercapai apabila paling sedikit $85 \%$ siswa di kelas telah tuntas belajar. Namun untuk SMP Negeri 22 Surabaya daya serap paling sedikit digunakan standart ketuntasan minimal (SKM) nilai 80. Untuk menghitung ketuntasan belajar secara klasikal digunakan rumus:

$\boldsymbol{E}=\frac{n}{N} \times 100 \%$, dimana:

$\mathrm{E}=$ persentase ketuntasan belajar klasikal $\mathrm{n}=$ jumlah siswa yang telah tuntas belajar $\mathrm{N}=$ jumlah seluruh siswa

\section{HASIL DAN PEMBAHASAN}

Bagian yang diperoleh setelah menerapkan pembelajaran problem based learning sebagai berikut:

\begin{tabular}{|l|c|c|c|}
\hline \multirow{2}{*}{\multicolumn{1}{|c|}{ Yang di observasi }} & \multicolumn{3}{c|}{ Capaian } \\
\cline { 2 - 4 } & $\begin{array}{c}\text { Pra } \\
\text { Siklus }\end{array}$ & Siklus I & $\begin{array}{c}\text { Siklus } \\
\text { II }\end{array}$ \\
\hline Jumlah Siswa yang diobservasi & 32 & 32 & 32 \\
\hline Jumlah Siswa yang telah tuntas belajar & 25 & 27 & 29 \\
\hline Ketuntasan belajar secara klasikal & $78,13 \%$ & $84,38 \%$ & $90,63 \%$ \\
\hline Rata-rata nilai siswa dalam kelas & 78,75 & 81,88 & 85,16 \\
\hline
\end{tabular}

Berdasarkan hasil penelitian diketahui bahwa terdapat peningkatan hasil belajar matematika siswa. Hal tersebut dapat dilihat pada pencapaian ketuntasan belajar 
secara klasikal pada pra-siklus $73,13 \%$, siklus I 84,38\%, dan siklus II 90,63\%.

Berdasarkan refleksi pada siklus I , peneliti malakukan beberapa revisi terhadap perangkat pembelajaran dengan menitikberatkan pada kekurangankekurangan yang dialami pada siklus I. Tindakan perbaikan yang direncanakan untuk dilakukan pada siklus II meliputi:

1. Pada pendahuluan guru menggunakan motivasi siswa dengan menggunakan bahasa yang mudah dipahami oleh siswa.

2. Pada LKS guru menggunakan variasi warna untuk menarik perhatian

3. Pada inti pelajaran guru lebih mendekatkan diri ke siswa, untuk mengetahui kesulitan siswa sejak dini.

Berdasarkan refleksi pada siklus II , hasil belajar yang diperoleh mengalami peningkatan yang signifikan bahkan telah mencapai ketuntasan belajar secara klasikal. Dengan demikian penelitian tindakan kelas selesai pada siklus II

\section{SIMPULAN}

Berdsarkan hasil pembahasan, maka dapat disimpulkan bahwa ada peningkatan hasil belajar matematika siswa kelas VIII-F SMP Negeri 22 Surabaya melalui penerapan model pembelajaran problem based learning pada materi sistem persamaan linier dua variabel.
Berdasarkan simpulan di atas, maka peneliti memberikan beberapa saran sebagai berikut:

Bagi guru, hendaknya memiliki komitmen yang tinggi dalam menjalankan tugas profesionalnya, untuk menerapkan berbagai inovasi pembelajaran secara variatif sebagai upaya meningkatkan hasil belajar matematika siswa.

Bagi sekolah, hendaknya ada fungsi kontrol terhadap komitmen guru dalam menjalankan tugasnya, sehingga tujuan yang diharapkan oleh sekolah dapat dicapai

\section{DAFTAR PUSTAKA}

Arikunto, S. 2007. Dasar-Dasar Evaluasi Pendidikan. (Edisi Revisi). Jakarta: Bumi Aksara.

Arikunto, Suharsimi. dkk. 2008. Penelitian Tindakan Kelas. Jakarta: Bumi Aksara.

Dimyati. Moedjiono. 2012. Belajar dan Pembelajaran. Jakarta: Rineka Cipta.

Huda, Miftahul. (2013). Model-Model Pengajaran dan Pembelajaran. Yogyakarta: Pustaka Belajar.

Isrok'atun dan Amelia Rosmala. (2018). Model-Model Pembelajaran Matematika. Jakarta: Bumi Aksara.

Karwono, H. dan Heni Mularsih. (2017). Belajar dan Pembelajaran. Depok: Rajawali Pers.

Ngalimun. (2012). Strategi dan Model Pembelajaran. Banjarmasin: Aswaja Pressindo 
Prayitno, Upaya Meningkatkan ...

Suharyanto, Tri. 2015. Intisari Matematika untuk SMP kelas 7-89. Bandung: Pustaka Setia.

Susanto, Ahmad. 2016. Teori Belajar \& Pembelajaran di Sekolah Dasar. Jakarta: Prenadamedia Group.

Undang-Undang. 2003. Undang-Undang Republik Indonesia No 20 tahun 2003 tentang Sistem Pendidikan Nasional. Jakarta: Asa Mandiri

Widada, Wahyu. 2004. Pendekatan Pembelajaran Matematika Berbasis Masalah. Surabaya: Yayasan Mitra Alam Sejati 